\title{
Dividend Payout Policy of Conventional Banking and Islamic Banking in Pakistan
}

\author{
Farhan Ahmed ${ }^{1}$, Abdul Rafay ${ }^{2}$, Afzal Ahmed ${ }^{3}$
}

\begin{abstract}
This paper investigates the difference between the dividend payout policy of Islamic banks and conventional banks in Pakistan for a period from 2012 to 2016 analyzing the data through regression using Least Square Method (OLS). Specifically, the study aims to study the impact of the profitability, liquidity, revenue growth and financial leverage on the dividend payout policy of the Islamic Banks and conventional banks of Pakistan and how Islamic banks dividend policy differs from conventional banks. This study concludes that the factors like liquidity and financial leverage should be considered and addressed accordingly, because these are key indicators to help policymakers and investors in assessing the performance of the Islamic Banking Industry.
\end{abstract}

Keywords: Islamic banking, conventional banking, dividend payout policy.

\begin{abstract}
Abstrak. Penelitian ini membahas perbedaan antara kebijakan pembayaran dividen bank syariah dan bank konvensional di Pakistan untuk periode 2012 sampai 2016 yang menganalisis data melalui regresi dengan menggunakan metode kuadrat sederhana (OLS). Secara khusus, penelitian ini bertujuan untuk mempelajari dampak profitabilitas, likuiditas, pertumbuhan pendapatan dan leverage keuangan terhadap kebijakan pembayaran dividen Bank Syariah dan bank konvensional Pakistan dan bagaimana kebijakan dividen bank syariah berbeda dari bank konvensional. Studi menyimpulkan bahwa faktor-faktor seperti likuiditas dan leverage keuangan harus dipertimbangkan dan ditangani sesuai, karena ini adalah indikator kunci untuk membantu pembuat kebijakan dan investor dalam menilai kinerja Industri Perbankan Syariah.
\end{abstract}

Kata kunci: perbankan syariah, bank konvensional, kebijakan pembayaran dividen.

\section{How to Cite:}

Ahmed, F., A. Rafay., \& A. Ahmed. (2018). Dividend Payout Policy of Conventional Banking and Islamic Banking in Pakistan. Al-Iqtishad: Jurnal Ilmu Ekonomi Syariah (Journal of Islamic Economics). Vol. 10 (1): 135 - 152. doi: http//dx.doi.org/10.15408/aiq.v10i1.6103 


\section{Introduction}

The banking sector is the critical part of the economy and performs an essential role in the economic activities; in the current era, the economy cannot act without the presence of adequate banking system. The traditional conventional economic system is based solely on providing funds and acquiring fund. The banks charge interest on providing funds and pay interest on obtaining funds from its depositors. This system contains high risk in the usage of funds and financial asset for the noneconomics activities because; banks cannot evaluate how the borrower utilizes the funds given. The main issue in this system, it is not compliant with Islamic Shariah (Ruling/Guidelines) because it contains the following elements: Riba (Interest), Gharar (A High-level of Uncertainty) Qimar (Gambling) and further it is not an asset-backed system in which may lead to highly hazardous financial situations. In the 19th century, Muslim scholars began working to create a banking system in which they would eliminate the non- Shariah elements that found in our current financial system. The Muslim Scholars create a banking system which excludes the following factors: Riba (Interest), Gharar (A High-level of Uncertainty), Qimar (Gambling) and makes it an asset-backed financial system. In the 2008 financial crises, there was a significant impact on the conventional financial institution due to the sub-prime mortgage which was not asset-backed instead it based on derivatives, which not permitted in the Islam. After the financial crises of 2008, the financial analyst and specialist analyzed that Islamic Financial and banking system not affected by this crisis and the growth of Islamic financial institution increased due to the global financial crises.

The investor is more comfortable to invest in the Islamic Financial Institutions as compare to the conventional financial institutions especially in Islamic countries, but the primary desire of the investors is to maximize the return on investments. This intention has caused an academic stampede to investigating the difference between Conventional banking and Islamic Banking systems and their Return on Investments. Furthermore, numerous accounts of studies have been conducted to compare the Islamic Banking sector with the Conventional Banking sector regarding their performance, return, growth, etc. However, only a few kinds of research have played attention and compared the Dividend policy of Islamic Banks and Conventional Banks. Almost every company earn profit through their economic activities and distribute this profit among their shareholders the mechanism of distributing profit is different according to the financial policy of the company and the growth opportunity of the company if the company have feasible growth opportunity then they reinvest their profit for the growth of the company. The process in which company defines that how much profit would distribute to 
the shareholder and what is the way for the distribution of profit is called dividend payout policy. Dividend payout policy varies in the different countries because of difference in the government regulations; tax policies different financial sectors and markets. There are variations in opinion about the impact of dividend payout on the shareholder's wealth. The first argument was there is no impact of dividend payout on the wealth of shareholder another argument was the dividend payout policy escalate the wealth of shareholder, the last debate was the dividend payout reduces the wealth of shareholder.

There is limited research conduct in Pakistan to determine the impact of dividend payout policy on the wealth of shareholders. There is also a debate that there is any difference between dividend payout of the financial sector and nonfinancial sector, the latest literature suggests that the dividend payout policy of the financial industry is different from the non-financial sector because of the different regulator and different policies like tax policies, retain earning strategies, growth opportunities. The purpose of this study is to examine the determinant of dividend payout policy of the Islamic banks and Conventional banks of the Pakistan. The study has investigated that what are the factors that affect the dividend payout policy of the banks and how they differ in case of Islamic banks and Conventional banks. In Pakistan, there is no tax on dividend till 2012 after that government imposes on $10 \%$ tax for filers and $15 \%$ for non-filers. Now, the withholding tax rate after the financial act 2015 under section 150 has also enhanced to $12.5 \%$ for filers and $17.5 \%$ for non-filers.

Dividend payout policy is critical for the investors and performs a vital role in motivating the investors toward investing in specific stock. Some models are developed to know the behavior of the investor concerning the Dividend payout policy of the companies. Dividend payout policy of the bank is the principal financial indicators concerning Pakistan's banking industry, which indicates bank performance and its growth in the emerging economy. Dividend payout policy also determines the return on investment of the investors, in this aspect, this is very important for the investors. This study aims to develop a model to determine the difference of the Dividend payout policy of Islamic Banks and Conventional Banks in Pakistan and how Islamic banks attract investors in Pakistan. This study will examine the effect of profitability, liquidity, financial leverage and revenue growth on the dividend payout policy of Islamic Banks and Conventional Banks of Pakistan.

There is some researchers question that addresses in this research. There are: First, what are the impacts of Profitability on dividend payout policy of Islamic Banks and Conventional Banks in Pakistan? Second, how the liquidity (Cash Flow) position of Islamic Bank and conventional banks of Pakistan effect on their 
Dividend Payout Policy. Third, financial leverage of Islamic Banks and conventional banks of Pakistan have an impact on their Dividend Payout Policy or not? Fourth, is there any impact of Revenue growth on dividend payout policy of Islamic Banks and conventional banks of Pakistan?

The structure of the paper divided into multiple sections. In the first section introduction along with research, the problem has discussed. In the second and third and fourth part, detailed literature review and evolution of banking sector in Pakistan elaborated. Result and discussion and conclusion sections are discussed as fifth and sixth section respectively.

\section{Literature Review}

The profit of the company, which distributed among the shareholders, is called dividend. The amount of dividend depends on the ownership of the number of shares. The dividend is the return on investment for the investors. The dividend may be in the form of cash, which means the company pays cash amount to the shareholders; sometimes dividend is in the form of stock dividends in which company issues new stock to the investors concerning their proportionate share of the investment.

There is some reason for which companies pay the dividend from their earnings to the shareholders; a healthy dividend amount shows that the companies have good revenues and have a financial strength. Through dividend investor receive their return on investment on the regular basis so those investors who want their gain on cash flow base, prefer those stocks who pay the reasonable amount of dividend. Firms who paid the reasonable amount of dividend had easy excess to the capital market. Furthermore, dividend payout policy also affects the valuation of the stock.

The Islamic banks of Pakistan have rapidly growing in the economy and have a significant share in the banking industry. There is literature found which compare the dividend payout policy of the Islamic and conventional banks. The objective and motivation of this study is to conduit the existing gap of literature Review by determining the factors that influence the dividend payout policy of the Islamic Banks and Conventional Banks of the Pakistan. To give the insight knowledge of dividend payout policy of Islamic Banks and Conventional Banks of the Pakistan to the investor to educate the investor to invest in Islamic Banks or conventional banks. Furthermore, this study also helps to the researchers, teachers, and students to understand the dividend payout policy of the Islamic and conventional banks of Pakistan and to do further research on the banking sector of Pakistan. The primary stakeholders of the study are investors, policymakers of the banks and the teachers, 
students, and researcher will be gaining the understanding of the Dividend payout policy of the banks of Pakistan.

The Islamic Banking industry of Pakistan is now a growing part of the financial sector of Pakistan, with high practical significance in different dimensions. The proven track record with a possessive growth rate, Islamic banking in Pakistan is now a big competitor of convention or traditional banking and financial system. The research basically conducted on the dividend payout policy of Islamic banking as compared to conventional banking and how it attracts the investors to invest in Islamic banking rather than conventional or any other financial system.

So this is definite form Quranic verse and hadith-e-Nabwi that riba strictly prohibited in Islam and this riba is part and parcel of the conventional banking system. Thus a limitation with Muslims by their religion not to go with riba and gharar, on the other end in today's world the world financial system works only with riba and gharar.

Islam prohibited Riba and gharar but gives its economics and financial systems. So by Islamic ideology, teaching, and philosophy, economic activity is essential for every individual. And with the help of Islamic teaching and guidelines, there was the need to focus the financial problems of the Muslim ummah and provide the superior model that can have rid of riba and gharar. Alhamdulillah by the grace of Allah a fundamental and strong financial facility is available now for Muslim Ummah that fulfills there day to day economic needs with Islamic banking and financial systems.

Now day's Islamic banking in Pakistan is emerging and growing at a rate of $15-20 \%$ yearly, and industry is looking a sharp rise in demand for Islamic financial services and products. Religion matters for Muslims, and now this can be seen that every conventional bank has Islamic banking window. This phenomenon is demand peoples are asking and moving towards Islamic banking from conventional. (Najaf, 2016)

When we have a view on the conventional banking system and Islamic banking systems, we find the difference with three major aspects: (Awan, 2009): First, socio-religious Level \& conceptual framework: Islamic Banks works on trading and investments model and not lend the money directly. The conventional banks involved directly in lending and borrowing business and also act only as the moneylender. Second, business Model \& Governing Framework: Islamic Banking works with a strict shariah governing framework having shariah guidelines and a board which approves every transaction $\&$ products in light of shariah rules and teaching. The conventional banks work on the interest-based structure. Third, 
Product Level Implementation: Islamic Banking products backed by assets and involve trading of assets, renting of assets and participation on profit and loss basis. Conventional banks treat money as the commodity and lend it against interest.

For fulfillment of the consumer needs, Islamic banking needs to work on the fulfillment of consumer requirements to compete with the conventional banks. Because banks profitability directly relates to the business comes towards Islamic banks and this business can only increase if the Islamic banks have true and positive alternatives of the conventional banks provide according to shariah rule and guidelines. (Khan, et al, 2012).

Islamic banking is going with a good pace in Pakistan as well as all over the world state bank of Pakistan is fully working with Islamic and enforcing commercial bank to come in the business of Islamic banking as a social and religious need of the economy. Customers are also demanding their banking needs from Islamic banking sector. In theory, Islamic banking differs from traditional, mainly because it does not allow banking interest (riba) in Islam. (Yahya et al. 2013)

Islam doesn't allow the collection and payment of interest (riba) preferably it based on mudarabah and musharakah the Islamic way of sharing profit and loss and distributing the risk and joint venture concept of Islamic contracting. Among the profit-loss sharing (PLS), assets and liabilities recognized in the sense that the borrowers share profits and losses at banks, which in turn share profits and losses to depositors (Chong \& Liu, 2009). In other words, Islamic banks better capitalized. In another study, studying Bashir (2000) shows that inflation does not affect the profitability of Islamic banks while conventional banks have ups and downs with inflation. Shariah compliance financial products have many advantages over conventional financial products. The shariah products remain safe from the world economic ups and downs that are the reason that Malaysian economy remains somehow sheltered from the world recession of 2008 due to having a stable Islamic financial system.

The dividend is the amount of money paid annually by the company to its shareholder. The dividend of any company is directly related to the profit of the company and the key indicators representing the financial stability of any company. The income investors and growth investor like financial growth regarding the balance sheet like dividend so that they have the capital gain regarding share prices. Dividend policy refers to the practice that the companies continue to pay dividends or decisions, in other words, the size and pattern of cash distributions to shareholders over time.

About the dividend decision companies have only two options; whether not to pay or to pay dividends. The payment of cash dividends is subject to the 
availability of cash and liquidity of the company. Many authors showed that there is a financial conflict between liquidity and profitability. Both the liquidity and profitability have an impact on the dividend policy of the company in general and banking in particular. The issue of the dividend is complicated. Essential elements are not hard to identify, but the interaction between these factors are involved and there are no easy answers (Ross 2009).

There is no tax on capital gain while $10 \%$ withholding tax on dividend payments. The government gives extension from 2012. So investors prefer capital gain to dividend income and work with the short-term scenario in stock markets. The banking sector is a very organized sector and having profit all the times, but profit is limited or increases with a percentage of a business increase. Less risk in the banking sector would have less profit.

Many theories have been proposed dividend to be executed a declaration of the dividend policy decisions gives and if you have an impact on the value of the company. Many factors influence distribution of cash dividend of profitability of the size of the active, low level of short-term payables, good relationships with suppliers in a strong liquidity position. Payment of corporate dividends is not only the source of cash flow for shareholders but also provides information on the current and future performance of the company. Typically, mature and profitable firms pay dividends. However, companies that pay dividends are not necessarily advantages. If a company thinks its growth prospects are better than the investment opportunities available to shareholders elsewhere, the company must retain the profits and reinvest in the business. Companies that effectively manage their cash flow tend to maintain and increase their dividend payments over time. Cash dividends related to funds available to pay dividends to shareholders in the short term. The liquidity of the company is dependent on the ability of the organization to their ability to put money to pay debts or other obligations. As a result, investors who need current and forecasted liquidity needs to spend a preferred dividend stocks.

Dividends are considered the most discussed topic in finance. In 1956, for the first time, John Lintner analyzed how companies deserve to distribute to shareholders and other business activities, such as taxes and depreciation, etc. Many times investors have no concerned with the dividends, but somehow dividend has its impact on the share price leads to capital gain for the investors (Theissen, 2014). There are some reasons why companies pay dividends from their profits to shareholders, an amount of healthy dividend that the company has a good profit and have a financial strength. By dividends, investors receive their return on investment on a regular basis so that investors base their performance on cash, preferred stock 
dividend reasonable amount. Companies that pay dividends sensitive amount of easy access to capital markets as well. Moreover, dividend payment policy took the impact of the valuation of the shares.

This fact is essential to learn the behavior of dividend policy as factors for smooth dividend payout varies concerning industries and time and the business turnover and payout ratio. Lintner originates that firms in the US adjust their dividends smoothly to maintain a target long run payout ratio. Lintner (1956) he further elaborates that smoothness is dividend policy varies from country to country, Institution to institution as well as capital market difference. Brealey and Myers said that dividends considered as the top crucial unanswered question in the field of advanced corporate finance. Brealey and Myers (2005). Black (1976) noted that dividends are the primary puzzle in the economics of finance.

Pakistan is called as an emerging market, and there is the clear difference between the dividend policy of the developed countries and emerging markets like Pakistan. And this is clear that in case of Pakistan determinants of dividend policy are not stable and may change from time to time, industry-to-industry and institution-to-institution.

Banking industry of any country directly depends on the economics, business and financial growth of that country. Banking moves with the economic growth and business opportunities available. And dividend policy of banking industry profoundly affects by any political instability or instability in the capital market or so-called as the stock market.

Baker and Wurgler (2004) have given the catering theory, which allows the companies to provide incentives to the investor as per their desires, and needs with an aim to cater the investors by paying smooth dividends. If investors put a premium on the stock price, the payer will not pay if the investors prefer to payers. Bhattacharya (1980) and John Williams (1985), gives signaling theory that explains dividends dispel knowledge to the managers and shareholders of the firms by providing inner knowledge of firm's future aspects. This also concluded that the dividend should pay to shareholders according to the prices of stocks. Eriotis' (2005) examine the effect of distributed earnings and size of the firms to its dividend policy of Greek firms. The author studied the Greek firms, set their dividend policies not only by net distributed earnings but also by the change in the dividend, the change from last year earnings and size of the firm. Baker et al.'s (2007) did work on the discernment of dividends by Canadian managers by having a sample size of 291 listed firms on Toronto Stock Exchange (TSE). Daniel et al.'s (2007) did work on whether firms manage earnings to meet the dividend threshold. They worked out that companies are more likely to manage their profits 
upward when their earnings would otherwise fall below expected dividend levels.

The dividend policy is important for managers and investors; therefore, that not only a source of income for investors, but it also reflects the performance. Selecting the appropriate dividend policy of the company is an important decision, the leaders, as well as the investor's Public companies; tend to assign the financial profit of the period, dividend investors. Dividend distribution policy determines the percentage of profit paid as a cover for the investors and the sample must keep for future investments, (Huda \& Farah, 2011). Their decision will depend on the current and future performance of the company. It also depends on the present and future investors preferences. Ahmed \& Javid worked on the market liquidity, and ownership concentration has an affirmative influence on dividend payout policy. Furthermore, they found that the investment opportunities and financial leverages have adverse control on dividend payout policy (Ahmed \& Javid, 2009).

Dividend policy is a debatable issue in the corporate world while having a good dividend policy. On the other end, there is the difference between determinants of the dividend policy for a company and a bank. Many investors prefer capital gain to cash dividends in Pakistan, which can be short-term phenomena to have good returns. (Hashim Zameer, 2013).

The study aims to find the Islamic banking as an attraction for the investors by comparing the conventional and Islamic performance towards the determinants of the dividends. The clear determinants are leverage, liquidity, revenue growth, and the most important profitability. These called as dependent variables of the research. The independent one is dividend payout ratio. The need is to find that even there is any attraction for the investors towards Islamic banking in Pakistan or they are motivated to provide their resources towards Islamic banking as a business attraction.

\section{Evolution of Banking Sector in Pakistan}

In 1977 Council of Islamic Ideology (CII) was appointed the task to prepare a draft of the Interest-free economy. In February 1979 President of Pakistan announced that interest would remove from the economy in 3 years. After this announcement House Building Finance Corporation (HBFC), National Investment Trust (NIT), and Mutual Funds Investment Corporation (MFIC) selected for removal of interest in their operations. In 1981 government gives the order to the commercial banks to establish Islamic counterpart on profit and loss sharing basis and this was continued till June 1985, after 1985 government gives the instruction to discontinued the parallel operation and allow only Profit and 
Loss sharing basis banking system. The movement toward the interest-free banking caused a sufferer of the economy and banks were allowed to invest their Profit and Loss sharing basis deposit in the interest-bearing government securities, and in 1991 the Federal Shariah Council declared this act as non-Shariah compliant. In the response of Federal, Shariah Council decisions the banks and government made appeals to the Shariah Appellate Bench of Supreme court of Pakistan. In 1991 the Sharia Appellate Bench rejected the request and imposed all rules and regulation of Riba on the banking.

The government set up a high-level commission, task forces and committees to institute and promotes Islamic Banking on a parallel basis with the conventional banking system. In 2004 the State Bank of Pakistan (SBP) established a dedicated Islamic Banking Department (IDB) and set a Shariah Board to regulate and approve guidelines for the emerging Islamic Banking industry.

\section{First Era 1948-1970:}

After the partition, the Banking sector was very limited in Pakistan only 631 branches are present in the country. Therefore, the State Bank of Pakistan was initially mandated to develop monetary stability and commercial banking channels to flourish trade and commerce activities in the country. Subsequently, Habib Bank, Allied Bank, and National Bank were amongst the first to start operation with the high coordination of the State bank of Pakistan.

\section{Second Era: 1970-1980:}

Commercial Banking was grown at the high pace which was favorable for the Pakistan until 1974 under the nationalization policy; thirteen banks were bought and consolidate these all into six government bank under full government control. The Pakistan Banking council was set up to monitor and control nationalized banks and to marginalize the role of State Bank of Pakistan as a regulator.

\section{Third Era 1980-1990:}

This is the awful era for the banking sector of Pakistan; the financial industry grew the large corporations, politicians, and the government. Board of Directors (BoD) and Chief Executive Officer (CEOs) were not independently appointed. Bank lending decision is not on proper credit \& risk assessment, and the lending is not commercially motivated. Billions of rupees unsurprisingly funneled out in the Financial \& Banking sector of Pakistan. 


\section{Fourth Era 1990-1997:}

In 1991 the act of bank nationalization was amended, and 23 domestic banks established in which ten banks domestically licensed. Muslim Commercial Bank privatized in 1991, and the majority owner of the Allied Bank was transferred to its management by 1993 . Further significant is the official interest rate was restructured, a system of auctioning government securities was introduced and bank wise credit ceiling amount was reduced. By 1997 there were still four government banks are present in Pakistan, but they faced great rivalry from 21 domestic banks and 27 foreign Banks.

\section{Fifth Era 1997-2006:}

After the privatization of banking sector, the power of State Bank of Pakistan as the regulator was reestablished after the amendment in the banking companies' ordinance 1962 and the State Bank of Pakistan 1965 Act. Subsequently, the internal controls, corporate governance, regulatory framework was strengthened. Legal impairments and delay in recovery of the bad loan were restructuring in 2001. Furthermore, the prudential regulation of 1989 was enhanced and allowing to banks to take exposure in that business which is previously unexploited. Banks also take exposure on small and medium enterprises and contribute to growing the small business in the economy.

\section{6 to Present:}

Being 2006 until present, the landscape of banking sector has been changed significantly. By 2010, five Public sector banks, six foreign banks, four specialized banks and 25 domestic banks were operative in the Pakistan. The total numbers of banks branches are 9,348. Now the banking sector of Pakistan is a strong part of the financial sector and plays an essential role in the development of the Pakistan's economy.

\section{Method}

The research philosophy of this study is positivist, and it is based on quantitative analysis. From approach point of view, this study is deductive and only taken one Islamic Bank and one Conventional Bank of the Pakistan. The first step in the research procedure is to develop the hypothesis, and the statistical model for the study secondly the researcher collects data from reliable sources after the collection of data. For analysis simple OLS (Ordinary Least Square) technique has been applied to analyze the effect of the different variable on the dividend payout ratio and this research is also based on the secondary data. The source for the collection of financial data is the published financial statements of the banks and 
Financial Statement Analysis prepared by State Bank of Pakistan (Central bank of Islamic Republic of Pakistan).

The sample period of the research is from 2012 to 2016 due to the limitation in the availability of the date. The quarterly observation was taken, so the sample size of the study is $\left(4^{*} 5^{*} 2=40\right)$ forty observations and twenty observations for each Islamic and Conventional bank. Hence, two separate regressions are computed, and results analyzed in the line of the research questions and objectives of the study.

The data of one Islamic Bank and one conventional bank is gathering. Table 1 shows the name of sample banks with their proper justification:

Table 1. Sample Banks

\begin{tabular}{lll}
\hline & Islamic Bank & Convectional bank \\
\hline Name & Meezan Bank Limited MBL & Bank Al-Habib Limited BAHL \\
Justification & $\begin{array}{l}\text { MBL is the one Islamic Bank } \\
\text { in Pakistan, which is listed in } \\
\text { the stock market, and pay the } \\
\text { dividend to their shareholders. }\end{array}$ & $\begin{array}{l}\text { BAHL is the conventional bank which } \\
\text { the balance sheet footage, Income statement } \\
\text { and number of branches near to the MBL. }\end{array}$ \\
\hline
\end{tabular}

Following regression equation is developed to test the hypothesis:

$$
\begin{aligned}
& \operatorname{IBDPR}_{t}=\beta 0+\beta 1 \mathrm{FL}_{t}+\beta 2 \mathrm{RoA}_{t}+\beta 3 \mathrm{Cash}_{t}+\beta 4 \mathrm{MTB}_{t}+\mu \\
& \mathrm{CBDPR}_{t}=\beta 0+\beta 1 \mathrm{FL}_{t}+\beta 2 \mathrm{RoA}_{t}+\beta 3 \mathrm{Cash}_{t}+\beta 4 \mathrm{MTB}_{t}+\mu
\end{aligned}
$$

Where:

$\mathrm{IBDY}_{\mathbf{t}}=$ Islamic Banking DPR in year $\mathrm{t}$

$\mathrm{CBDY}_{\mathbf{t}}=$ Conventional Banking $\mathrm{DPR}$ in year $\mathrm{t}$

$\mathrm{FL}_{\mathbf{t}} \quad=$ Financial Leverage in year $\mathrm{t}$

$\mathrm{RoA}_{\mathbf{t}}=$ Return on Asset in year $\mathrm{t}$

Cash $_{\mathbf{t}}=$ Cash flow in year $\mathrm{t}$

$\mathrm{MTB}_{\mathbf{t}}=$ Investment opportunities (Growth) in year $\mathrm{t}$

\section{Results and Discussion}

The Mean of dividend payout ratio (DPR) of the conventional bank is $6.7 \%$, which is higher, compare to the Islamic Bank dividend payout ratio $5.01 \%$ because when the company has the growth opportunity tend to be paid the low dividend. This result shows that Islamic Bank has higher growth opportunities as compares to the conventional Bank. Growth opportunities (Market Book value MTB) of 
Islamic Bank is also high (1.61x) concerning the conventional bank $(1.5 \mathrm{x})$ which also support the low dividend amount.

Table 2 Descriptive Statistics

\begin{tabular}{lccccc}
\hline \multicolumn{1}{c}{ Islamic Bank } & CASH & DPR & FL & MTB & ROA \\
\hline Mean & 0.095950 & 5.014000 & 0.066450 & 1.617000 & 0.009320 \\
Median & 0.097000 & 4.970000 & 0.069000 & 1.655000 & 0.010400 \\
Maximum & 0.117000 & 7.100000 & 0.079000 & 2.010000 & 0.012800 \\
Minimum & 0.078000 & 3.050000 & 0.050000 & 1.140000 & 0.002000 \\
Std. Dev. & 0.011166 & 1.212468 & 0.010570 & 0.240397 & 0.003948 \\
\hline Conventional Bank & CASH & DPR & FL & MTB & ROA \\
\hline Mean & 0.067873 & 6.7135 & 0.155844 & 1.507416 & 0.011387 \\
Median & 0.068194 & 7.06 & 0.169917 & 1.521095 & 0.011276 \\
Maximum & 0.075229 & 11.76 & 0.179481 & 1.658085 & 0.012175 \\
Minimum & 0.062701 & 2.73 & 0.121922 & 1.217127 & 0.010806 \\
Std. Dev. & 0.004568 & 2.182881 & 0.023358 & 0.1593 & 0.000477 \\
\hline
\end{tabular}

The profitability (mean of ROA) of the Islamic bank is slightly low $(0.9 \%)$ as compared to the conventional bank $(1.1 \%)$ this is due to non-availability of the better investment avenues for the Islamic Bank concerning the conventional bank. The high liquidity of Islamic Bank, i.e., 95\% shows that Islamic Bank has an issue to invest their excess liquidity while the conventional bank has low liquidity issue; the mean of conventional bank liquidity is $67 \%$ (See Table 2).

Financial leverage of the Islamic Bank is $6.6 \%$ which is much better than the conventional bank's financial leverage $15.58 \%$ this shows that conventional bank has more debt as compared to the Islamic Bank. Furthermore this is against the literature because literature says the high financial leverage is a cause of low dividend but in this case, the conventional bank pays high dividend with high financial leverage and Islamic bank pay low dividend with little financial leverage.

The researchers have used OLS the regression method as major analytical tools. The ordinary least square or linear least square is a way of estimating the unknown parameters in a linear regression model. The value of the variable predicted through ordinary least square. Deals with two types of variables dependent and independent variables, also work on time series data. In a data series independent variable is used as input and the dependent variable used as output due to prediction. The OLS is a most common effective and efficient method used by the researcher in 
academic, essential experimental and applied research to complete their analysis and have findings.

Table 3. Ordinary Least Square (Islamic Bank)

\begin{tabular}{|c|c|c|c|c|c|c|}
\hline $\begin{array}{l}\text { Dependent } \\
\text { Variable }\end{array}$ & $\begin{array}{c}\text { Independent } \\
\text { Variable }\end{array}$ & Coefficient & Std. Error & t-Statistic & Prob. & R-squared \\
\hline \multirow[t]{4}{*}{ DY } & FL & 93.45512 & 27.31410 & 3.421497 & 0.0051 & 0.780595 \\
\hline & ROA & 537.9862 & 119.6641 & 4.495801 & 0.0007 & \\
\hline & Cash & -36.86363 & 21.27458 & -1.732755 & 0.1087 & \\
\hline & MTB & -4.447722 & 0.703508 & -6.322202 & 0.0000 & \\
\hline & $D Y_{t}=\beta 0$ & $\begin{array}{r}\text { Regressic } \\
\text { FL }_{t}+\beta 2 \text { Ro } \\
\end{array}$ & $\begin{array}{l}\text { Equation } \\
+\beta 3 \text { Cash }_{t} \\
\end{array}$ & $4 \mathrm{MTB}_{\mathrm{t}}+$ & & \\
\hline
\end{tabular}

Table 3 shows the result of the regression equation of Islamic bank; the first equation estimates the impact of financial leverage, Return on the asset, cash, and market to book value of the share on the dividend payout ratio of Islamic Bank. The result of ordinary least square (OLS) shows that there is no impact of cash (liquidity) on the Islamic Bank dividend payout ratio and other variables affect the dividend payout ratio. The financial leverage and return on asset have a positive impact on dividend payout ratio while Market to book value of the share hurts the dividend payout ratio of the Islamic bank. The results of the study related to the adverse impact of financial leverage on dividend payout ratio is insignificant, and the findings are not supported (See Hashim Zameer, 2013). The results of the study show that the impact of profitability (ROA) on dividend payout ratio recommended in the literature (See Khoury, 2014). The value of R-squared is $78 \%$, which means the econometric model of dividend payout ratio of Islamic Bank is the good fit.

Table 4 shows the result of the regression equation of Conventional bank; the second equation estimates the impact of financial leverage, Return on the asset, cash, and market to book value of the share on the dividend payout ratio of conventional Bank. The result of ordinary least square (OLS) shows that there is no significant impact of return on the asset on the conventional Bank dividend payout ratio and other variables have a substantial effect on the dividend payout ratio. The financial leverage cash have a positive effect on dividend payout ratio while Market to book value of the share has a negative impact on the dividend payout ratio of the Islamic bank. The amount of R-squared is $81 \%$, which means the econometric model for the dividend payout ratio of convention bank is also good fit. 
Table 4. Ordinary Least Square (Conventional Bank)

\begin{tabular}{|c|c|c|c|c|c|c|}
\hline $\begin{array}{c}\text { Dependent } \\
\text { Variable }\end{array}$ & $\begin{array}{c}\text { Independent } \\
\text { Variable }\end{array}$ & Coefficient & Std. Error & t-Statistic & Prob. & R-squared \\
\hline \multirow[t]{4}{*}{ DPR } & FL & 14.58660 & 17.43977 & 0.836399 & 0.4193 & 0.815313 \\
\hline & ROA & 35.95766 & 712.9161 & 0.050437 & 0.9606 & \\
\hline & Cash & 496.0626 & 91.75960 & 5.406111 & 0.0002 & \\
\hline & MTB & -6.958922 & 2.296421 & -3.030334 & 0.0105 & \\
\hline \multicolumn{7}{|c|}{ Conventional Bank } \\
\hline
\end{tabular}

The result of the study does not reject the $\mathrm{H}_{3}$ and $\mathrm{H}_{4}$ of the Islamic banks it means profitability have a significant positive impact on the dividend payout of Islamic Bank and revenue growth have a significant negative effect on the dividend policy of the Islamic bank. The result of the study reject the $\mathrm{H}_{1}$ and $\mathrm{H}_{2}$ of Islamic Bank it means the liquidity have no significant impact on the dividend payout of Islamic bank while financial leverage has significant positive impact on the Islamic bank dividend policy.

Following may be the reasons for no significant impact of liquidity on the dividend payout of Islamic Bank: First, Islamic banks have excess liquidity of depositor fund that may not use for the dividend payout. Second, Islamic bank does not have a proper invest avenues and financial markets like conventional banks. Third, Islamic bank cannot invest in government securities because they are interest-bearing securities. However, the amount of Sukuk issued by State Bank of Pakistan has not fulfilled the requirement of Islamic banking. Fourth, a large amount of syndication for the huge project of in the economy comes from the conventional banking; unfortunately, Islamic bank cannot play a meaning full role in the syndications. The financial leverage has significant positive impact on the dividend policy while literature suggests that the financial advantage have the adverse effect on the dividend policy. Following may be the reasons for the positive effect of financial leverage on Islamic Bank dividend: Financial leverage of the companies which defined in the literature determined by dividing debt to the equity but in the case of bank the financial leverage determined by the total debt (which include depositor's liability). The business model of the banks is entirely different as compared to the regular business model. In the regular business model the high financial leverage is the cause of high-interest expense, which declines the bottom line profit of the company, and finally, the high leverage will decline the dividend ratio.

Results of the study do not reject $\mathrm{H}_{2}$ and $\mathrm{H}_{4}$ of the conventional bank it means the significant positive relationship existed between the liquidity and dividend payout of the conventional bank and revenue growth have a significant negative impact on the dividend payout. The result of the study reject $\mathrm{H}_{1}$ and $\mathrm{H}_{3}$ 
of the conventional bank, it means financial leverage and return on asset leverage have no significant impact on the dividend payout of the conventional bank. The reason for the rejection of $\mathrm{H}_{1}$ same as defined in above Islamic Banking result. The no significant effect of return on the asset on the dividend payout shoes that conventional bank pay dividend regardless of the return on asset.

Islamic bank and the conventional bank has same effect of the revenue growth, and financial leverage have the similar effect on the dividend payout ratio, revenue growth is negatively related as suggested in the literature while financial leverage has no significant negative impact on the dividend payout ratio which is not supported by the literature or theory. Liquidity have the different impact on the Islamic bank dividend payout ratio and conventional bank dividend payout ratio; conventional bank liquidity has the significant positive impact on dividend payout ratio as literature suggested while Islamic bank liquidity has no significant impact on the dividend payout ratio because of the liquidity issues in the Islamic bank. Islamic bank profitability have the significant positive impact on the dividend payout ratio as literature suggested while conventional bank have no impact on profitability on their dividend payout ratio it means conventional bank pay dividend regardless with their profitability.

\section{Conclusion}

This paper examined the determinants of the dividend policy of Islamic banks and conventional banks in the Pakistan and determines the difference between dividend policy of Islamic banks and conventional banks from 2012 through 2016. The analysis reveals that the Islamic bank financial leverage and profitability have the significant positive association with the dividend policy while revenue growth has negatively related to the dividend policy of Islamic bank. While for conventional bank liquidity has the strong significant positive association with the dividend payout policy of conventional bank while revenue growth negatively related to the dividend policy of the conventional bank. The results show that conventional banks pay more dividends as compare to the Islamic banks because the profitability of the conventional bank is slightly higher and they pay the dividend without consideration of profitability this can be due to the higher growth opportunities of the Islamic banks. The research accomplishes that the Islamic banks are struggling to commit the stable dividend policy while conventional banks dividend payouts are random and subjective and not in the form of policy. Although the negative relationship with liquidity (free cash flow) in Islamic bank is not significant, it may create shareholder expropriation and raises a red flag about the severe problem of agency theory. This research paper recommends the management of Islamic banks and conventional banks to give attention to setting their dividend payout policy because the dividend influence the investor's behavior regarding investment in the specific stock. 
The result of this study has practical implications for analyst, investors and especially bank's management. Identifying the primary determinants of the dividend policy helps investors and analyst to build up their forecasts and select appropriate valuation model. The research paper attempts by Islamic bank to commit a sustainable dividend payout policy, which attract the investors to invest in the Islamic bank. The result of the study should encourage BoDs, financial analyst, policymakers and investors in Pakistan to use the dividend to monitor the agency theory especially for the Islamic banks to strengthen the trust of the investor on the Islamic banking.

Future research may conduct to determine the impact of other variables on dividend policy, which can include ownership variables in the regression equation to examine the agency theory regarding dividend. Furthermore, future study should cover more than one country because the review is limited to the banking sector of Pakistan.

\section{References}

Ahmed, H., \& A.Y. Javid. (2009). Determinants of Dividend Policy in Pakistan. International Research Journal of Finance and Economics. 29: 110- 125.

Al-Kayed, L. T., \& L.T. Al-Kayed. (2017). Dividend Payout Policy of Islamic vs Conventional Banks: Case of Saudi Arabia. International Journal of Islamic and Middle Eastern Finance and Management. 10(1): 117-128.

Allen F., \& R. Michaely. (2003). Payout Policy. In Constantinides, G.M., M. Harris., R.M. Stulz (ed). Handbook of the Economics of Finance. Netherland: North Holland.

Al-Najjar, B., \& K. Hussainey. (2009). What Drives Firms' Capital Structure and Dividend Policy. Working paper. London: Middlesex University.

Andres, C., M. Doumet., E. Fernau., \& E. Theissen. (2015). The Lintner Model Revisited: Dividends Versus Total Payouts. Journal of Banking \& Finance. 55: 56-69.

Awan, A. G. (2009). Comparison of Islamic and Conventional Banking in Pakistan. Proceedings 2nd CBRC. Lahore, Pakistan.

Baker, M., \& W. Jeffrey. (2004). A Catering Theory of Dividends. Journal of Finance. 59: $1125-1165$

Baker, H.K., S. Saadi., S. Dutta., \& D. Gandhi. (2007). The Perception of Dividends by Canadian Managers: New Survey Evidence. International Journal of Managerial Finance. 3 (1): 70-91. doi: 10.1108/17439130710721662.

Berkley R. \& S. Myers. (2005). Principles of Corporate Finance. 8th edition. London: McGraw-Hill.

Bhattacharya, S. (1979). Imperfect Information, Dividend Policy, and "The Bird in the Hand" Fallacy. Bell Journal of Economics. 10(1): 259-270. 
Black, F. (1976). The Dividend Puzzle. The Journal of Portfolio Management. 2(2): 5-8. De Angelo, H., L. De Angelo., \& D.J. Skinner. (2004). Are Dividends Disappearing? Dividend Concentration and The Consolidation of Earnings. Journal of Financial Economics. 72(3): 425-456.

De Angelo, H., L. De Angelo., \& R.M. Stulz. (2006). Dividend Policy and The Earned/Contributed Capital Mix: a Test of the Life-Cycle Theory. Journal of Financial economics. 81(2): 227-254.

Eriotis, N. (2011). The Effect of Distributed Earnings and Size of the Firm to Its Dividend Policy: Some Greek Data. International Business \& Economics Research Journal (IBER). 4(1): 67-76.

Hasan, M., \& J. Dridi. (2010). The Effects of The Global Crisis on Islamic and Conventional Banks: A Comparative Study. Journal of International Commerce, Economics and Policy. 2(2): 163-200.

Huda, F., \& T. Farah. (2011). Determinants of Dividend Decision: A Focus on Banking Sector in Bangladesh. International Research Journal of Finance and Economics. 77: 33-46.

Khan, F.U., B. Khan., Z. Awan., T. Hassnain., \& A. Javed. (2012). Growth of Islamic Banking in Pakistan: A Comparative Study. Research Journal of Finance and Accounting. 3 (2): 25-34.

Kohli, H. S., A. Sharma., \& A. Sood. (Eds.). (2011). Asia 2050: realizing the Asian century. New Delhi: SAGE Publications India.

Lintner, J. (1956). Distribution of Incomes of Corporations Among Dividends, Retained Earnings, and Taxes. The American Economic Review. 46(2): 97-113.

Maldajian, C., \& R. El Khoury. (2014). Determinants of the Dividend Policy: an Empirical Study on the Lebanese Listed Banks. International Journal of Economics and Finance. 6 (4): 240-250.

Merchant, I. P. (2012). Empirical Study of Islamic Banks versus Conventional Banks of GCC. Global Journal of Management and Business Research. 12(20): 32-42.

Najaf, R. N. (2016). Growth of Islamic Banking in Pakistan. Global Journal of Management And Business Research. 16(5): 34-45.

Shirvani, H., \& B. Wilbratte. (1997). An Empirical Investigation of Asymmetric Behavior in Corporate Dividend Policy. Economic Inquiry. 35(4): 847-857.

Yahya, M. H., J. Muhammad., A. Abdullah., \& A.M. Nasir. (2013). Chinks in the Capitalism System -The Pertinence of Islamic Finance. Journal of International Business and Cultural Studies, 7(1): 1-13.

Zameer, H., S. Rasool., S. Iqbal., \& U. Arshad. (2013). Determinants of Dividend Policy: A Case of Banking Sector in Pakistan. Middle-East Journal of Scientific Research. 18(3): 410-424. 